the problems of ancient rocks; Murchison Medal, to Prof. K. C. Dunham, professor of geology, University of Durham, in recognition of his contributions to geology and especially the study of ore deposits and their genesis; Lyell Medal, to Prof. S. I. Tomkeieff, professor emeritus, University of Newcastle upon Tyne, for his contributions to mineralogy and petrology and his exposition of the works of Russian geologists; Prestwich Medal, to Mr. D. Curry, managing director (joint), Currys, Ltd., for his work on the English Lower Tertiary rocks and his contributions to the geology of the English Channel and Western Approaches; Wollaston Fund, to Miss E. M. Guppy, senior experimental officer, Geological Survey and Museum, for contributions to the work of the Geological Survey, especially in petrology; Murchison Fund, to Prof. J. G. Ramsay, Department of Geology, Imperial College of Science and Technology, for his contributions to structural geology, particularly in the Scottish Highlands, Transvaal and the Alps; $a$ moiety of the Lyell Fund, to Dr. M. J. S. Rudwick, lecturer in geology, University of Cambridge, for his substantial work in developing the field of functional morphology in palaeontology and for his contributions on the history of geology; and to Mr. J. R. L. Allen, lecturer in goology, University of Reading, for his work in sodimentology.

\section{Philosophical Society of Washington}

Dr. M. M. Shapiro, head of the laboratory for cosmicray physics at the U.S. Naval Research Laboratory, has been elected president of the Philosophical Society of Washington. Dr. W. J. Youden, of the George Washington University, and Dr. E. Montroll, vice-president for research at the Institute for Defense Analyses, have been elected vice-presidents of the Society.

\section{Technion Achievement Award}

THE Chicago Chapter of the American Society for Technion, Israel Instituto of Technology, Inc., has announced the establishment of a Technion Achievement Award. The award, including an honorarium of 1,000 dollars, will be given for some successful application of technology to an important social problem. Nominations for the Award, which will be given this year for an achievement noted in 1965, should reach Dr. Herbert H. Hyman, secretary, Technion Achievement Award Committee, 59 E. Van Buren Street, Chicago, not later than July 1, 1966.

\section{Annual Prize for Women Undergraduates}

A PRIZE of $£ 15$ is offered by the British Federation of University Women, Ltd., for an essay on one of the following subjects: $(a)$ expectation and reality on entering a University; (b) the responsibilities of teachers and students. Competitors should be women students reading for a first degree or diploma at any University or College of Advanced Technology in England, Scotland or Wales. Further information can be obtained from the Secretary, British Federation of University Women, Crosby Hall, Cheyne Walk, London, S.W.3, to whom ontries should also be sent. The closing date for the competition is May 1 .

\section{Esso Chemical Limited}

Esso Petroleum Company, Ltd., has announced that the management. and operation of its present chemical business will shortly be transferred to a new company, Esso Chemical, Ltd., which will also be responsible for the future development of the chemical business of Esso in the United Kingdom. The new company will be wholly owned by Essu Chemical Company, Inc., of New York, which is in turn a wholly owned subsidiary of Standard Oil Company (New Jersey).
"A Wave Mechanical Approach to the Plasma Interaction Problems"

Prow. V. C. Lru (Department of Aerospace Engineering, College of Engineering, University of Michigan, Ann Arbor) has notified the Editor of the following corrections to "A Wave Mechanical Approach to the Plasma Interaction Problems", which appeared on p. 883 of the November 27, 1965, issue of Nature: "Equations (7a), $(7 b),(8)$ and $(9)$ should read:

$$
\begin{aligned}
\frac{\mathrm{d}^{2} \psi_{1}}{\mathrm{~d} x^{2}}+\frac{8 \pi^{2} m}{h^{2}}[E e-\varphi(x)] \psi_{1} & =C_{1}^{2} \psi_{1} \\
\frac{\mathrm{d}^{2} \psi_{2}}{\mathrm{~d} y^{2}} & =-C_{1}^{2} \psi_{2} \\
\mid \zeta^{2}=\left(1-e \varphi / E \cos ^{2} \theta\right)^{-\frac{1}{2}} &
\end{aligned}
$$

and

$$
\begin{aligned}
& x-x_{0}=\int_{\varphi_{0}}^{\varphi}\left(8 \pi n_{0}\right)-\frac{1}{2}\left[2 E \cos ^{2} \theta\left(\sqrt{1-e \varphi / E \cos ^{2} \theta}-1\right)-\right. \\
&\left.x T_{e}\left(1-e^{e \varphi / x T_{e}}\right)\right]^{-\frac{1}{2}} \mathrm{~d} \varphi
\end{aligned}
$$$$
\text { respectively". }
$$

\section{University News:}

Edinburgh

THE following lecturers have been appointed: Dr. A. J. Crosbie (geography); Dr. J. S. Kelly (pharmacology). The status of reader has been conferred on the following : Dr. J. H. Bowie (bacteriology); Dr. R. M. Gaze (physiology); Dr. F. L. Mitchell (clinical chemistry); Dr. P. H. Davis (botany) ; Dr. J. H. Knox (physical chemistry) ; Dr. J. B. Sissons (geography).

London

Prof. K. G. Denbigh, at present Courtaulds professor of chemical engineering at the Imperial College of Science and Technology, has accepted the office of principal of Queen Elizabeth College in succession to Miss M. J. Sargeaunt, who will be retiring on September 30 .

Newcastle upon Tyne

THE following lecturers have been appointed: Dr. D. F. Roberts (human genetics); Dr. H. C. Noltimier (geophysies); Mr. P. Baldwin and Dr. J. P. Baty (engineering mathematies); Mr. A. T. B. Moffat (civil engineer ing materials).

\section{Announcements}

Prof. A. R. J. P. Uвbelohde has been appointed to fill a vacancy in the membership of the Agricultural Research Council, which has arisen on the resignation of Prof. W. T. Williams.

Mr. A S. Foot, head of the Department of Dairy Husbandry of the National Institute for Research in Dairying, has been appointed deputy director of tho Institute.

A THREE-DAY course on "Temperature Measurement" will bo held at the Woolwich Polytechnic during March 16-18. Further information can be obtumed from P. R. Pallister, the Woolwich Polytechnic, Wellington Street, London, S.E.18.

A symposrum on "Early Crop Production in the British Isles" will be held in the University College of Wales, Aberystwyth, on March 9. Further information ean be obtained from J. A. Taylor, Department of Geography, Llandinam Building, Penglais, Aberystwyth.

A MEETING of the Welsh Soils Discussion Group on "Soil as a Biological Environment," will be held at the Welsh Plant Breeding Station, Gogerddan, on Febmuary 16. Further information can be obtained from C. Rudeforth, Soil Survey, National Agricultural Advisory Service, Trawscoed, Aberystwyth. 